報交

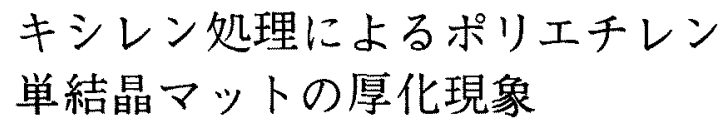

群馬大学工学部 町田等久・山本婎三 斉藤安史・木下茂武

\title{
SOME EXPERIMENTS IN THE THICKENING PROCESS OF POLYETHYLENE CRYSTAL MATS TREATED IN XYLENE
}

\author{
By Morihisa Machida, Yuzo Yamamoto, Yasushi Saito and Shigetake Kinoshita
}

(Faculty of Engineering, Gunma University, Kiryu-City, Japan)

The morphological changes of polymer crystals during isothermal annealing are usually observed in the medium of air. Single crystal mats of polyetylene (unfractionated) used here were annealed isothermally in xylene for various times. The treated samples were quenched in $0{ }^{\circ} \mathrm{C}$ methanol and dried in vacuo at room temperature.

The observations of weight loss, long period, molecular orientation and melting point for dried samples were compared with those of the mats annealed directly in air, as a function of treating temperature $T_{a}$ and time-interval $t_{a}$. The main results obtained are as follows;

(1) At the temperature below $T_{a}=90^{\circ} \mathrm{C}$, the weight losses of dried samples were not detectable, where the long spacings of the samples also remained unchanged on the small-angle $\mathrm{X}$-ray pattern like that of untreated original one. It was assumed that xylene acted only as swelling agent for polyethylene at considerably·low temperatures.

(2) Upon increasing the temperature higher than $T_{a}=92{ }^{\circ} \mathrm{C}$, the weight losses of dried samples became more noticeable, at the approach of $T_{a}=100^{\circ} \mathrm{C}$ loss-isotherms levelled off after few minutes. In these stages the dissolved polymers recrystallized rapidly at the surfaces of the remaining crystals. It was interesting to note that the small-angle diffraction patterns of the samples treated at $T_{a}=92^{\circ} \mathrm{C}\left(t_{a}=10 \mathrm{~min}\right.$.) or $T_{a}=95^{\circ} \mathrm{C}$ $\left(t_{a}=1 \mathrm{~min}\right.$.) showed coexisting of two long periods corresponding to the initial and the increased new thicknesses.

(3) At the temperature between $T_{a}=92^{\circ} \mathrm{C}\left(t_{a}<600 \mathrm{~min}\right.$.) and $100^{\circ} \mathrm{C}(<10 \mathrm{~min}$.), the characteristic phenomena on WAXS patterns for the dried samples were that the orientations remained unchanged, and those on DSC thermograms were that the single sharp melting peaks were preserved during the fusion of samples.

(Received April 24, 1974)

\section{1. 緒 言}

熱処理による高分子結晶の厚化現象については、二つ の機粠が提唱されている。一つは結晶状態をほぼ保ち， 分子全体の運動により“すべり払散”をおこし，厚化核 を形成し厚化してゆくとする平井ら”, Peterlin ${ }^{8 〉}$
のZeiphasige Neukristallisation説であり，もう 一つは，より薄い部分がまず蛅解し，まだ融解していな い部分を核として再結晶し，そのさいより曆い結昆に成 長するとする河合 ${ }^{8)} ら の$ Einphasige Rekristallisation説である。しかし実際の厚化には，このような機 構が部分的に関与する現象なども知られていて ${ }^{18)}$ ，まだ 
確定した統一的な結論が出ていないのが現状である。厚 化現象は分子鎖の折れたたみ，高分子の結晶化などの基 本的問題にかがわる重要な性質を有していると思わ机る。

この熱処理は，空気中の d ry 状熊で行われるのが普通 であるが，もし適当な媒質中に浮かして wet 状態で実施 すれば, dryのときの融解に対して, 膨潤, 溶解, 分解 などの作用が㧍こることが期待される゙,8,18〜1b)。これら の処理中に束縛から解放され relax した分子鎖梳、処理 時間や温度などで規定される一層安定な状態を占めるよ うな仕方で再配列するのであろら”。 wet 処理では直接 その状態に扰ける観測が望ましいが，処理試料を冷却， 洗浄、乾操してdry 状態にして間接的に処理経過を涮定 することも多い。

本報では，未分別ポリエチレン(PE) 単結晶マットを 用いて，従来から報告されている厚化特性を再確認しな がら，特に空気中熱処理とキシレン処理した雗躁物とで それぞれのラィラ層厚の変化にどのような差異があるか を検討した。熱処理某質としてキンレン液を用いたのは， 今回のよ5に望気中の螱解举動に对して溶解举動を較心゙ るばあい，PEが溶け易いこと，また再結晶化による長 周期のデータが得られやすいことなどである。結果的に は，空気中処理とキシレン処理とで怯，層厚の变化に伴 う配向の変化や融解ピークの形など形態的に 2,3 の相違 が認められた。この差異は、キシレン中では部分溶解と 再結晶が抗こなわれ，空気中熱処理では部分融解，再結 晶が生じているとすれば，見かけ上の現象とも解秎でき るものであった。以下それらについて，実験事実を主と して報告する。

\section{2. 試料の作製と実験方法}

\section{1 単結晶マットの作製}

末分別ポリエチレンHizex 5000 Sを用い，単結晶は $0.05 \%$ \% シンン希薄溶腋加等温析出させた。結昆化温 度は $77 \sim 77.8^{\circ} \mathrm{C}$ と $80 \sim 83^{\circ} \mathrm{C}$ の二種類である。以後それ ぞれを $T_{c}=77+, T_{c}=80$ +試料と呼ぶ。結晶化時間はい ずれも 30 時間である。結晶化温度で吸引口過してマ, トを作製した。マットの厚さは $T_{c}=77$ 十試料で平均 0.19 $\mathrm{mm}, T_{c}=80$ +試料で注平均 $0.24 \mathrm{~mm}$ であった。作製し たマットは沪紙とガラス板に摤み軽いブレス状態で真空 稪燥と $40^{\circ} \mathrm{C}$ 温度下での乾燥上者重量変化のなくなるまで 繰返した。

$\mathrm{X}$ 線小角測定による長周期は $T_{c}=77$ +試料では $115 \AA ̊$. $T_{\mathrm{c}}=80$ +試料では $120 \AA ̊$ 它あった。(以後, この $T_{c}=77+$ 試料, $T_{c}=80$ +試料の末熱処理物を都合で Original と 呼ぶことにする。

\section{2 熱処理操作}

（1）空気中の熱処理と急泠

単結晶マットを $8 \times 10 \mathrm{~mm}^{2}$ の短冊形に切り、フルミ籍 に包及所定の温度に保った $\left(\right.$ 精度 $\left.\pm 0.1^{\circ} \mathrm{C}\right)$ ×レンタラ イコール中で熱処理した。アルミ簿に包むさい，恄料か 熱処理中に外気にふれることのない様十分注意した。所 定時間熱処理後ただちに氷水中に入れて急冾した。

（2）キシレン液中の熱処理，急冷と䡚恽

所定の温度にセットした $400 \mathrm{cc}$ キシレン中で㧍こな った。熱処理中に溶けでたポりマーの付着を避けるため， $92^{\circ} \mathrm{C}$ から 60 分以上に処理したものはその度に新しいキ シレンと取替えた。末処理試料の重さは平均して $0.011 \mathrm{~g}$ である。所定時間熱処理後とり出し，冾却後メチルアル コールに約 10 時間浸瀆，それから真空乾燥した。重量 損失柱情度 $0.1 \mathrm{mg}$ 末での科量で求めた。（以後，この試 料を単にキシレン処理試料と呼ぶ。)

\section{（3）昇温，降温による熱処理}

Original 試料約 $3 \mathrm{mg}$ 党後述の DSC 測定器にセッ卜 し, $8^{\circ} \mathrm{C} / \mathrm{min}$ で昇温, 所定の温度に達したならば hold して所定時間熱処理した後， $8^{\circ} \mathrm{C} / \mathrm{min}$ で降温した。室温 までさげたのち，再び $8^{\circ} \mathrm{C} / \mathrm{min} て ゙$ 界温した。この全経過 をサーモタラムに記録した。

\section{$2.3 X$ 線回折測定}

小角X線回折には，理学電機整口ーターフレックスを 用いた。スリット采注第一スりタト $0.5 \mathrm{~mm} \phi$ ，第 2 スり ット0.2 mmゆのピンホールで主に扔こなった。カメラ 長は $300 \mathrm{~mm}$ である。

広角X線回折测定は，理学電機製ガイガーフレックス で回折写真を元、同社製ローターフレックスで回折強度 を記䩮した。

\subsection{DSC 測定}

Perkin-Elmer DSC - 1B 型を用い，具温速度は8 ${ }^{\circ} \mathrm{C} /$ min である。温度補正に性安息香酸とインシュームの 融点を用いた。歌解熱恃安息香酸 (触解熱 $33.9 \mathrm{cal} / \mathrm{g}$ ) を標準物質として算定した。融点恃㜔解ビーク温度をと った。

\section{5 シリコンオイル処理}

$92^{\circ} \mathrm{C}$ 以上でキシレン液中熱処理した翰蜗試料は，小角 X 線回折像が空孔によると思われる中心散漫散乱によ。 て，缯厚による回折像が招括われていて，長周期が㴊定 できなくなる。このため次のようなッリコンオイル观理 を行った。

キシレン処理試料を室温で約 5 時間真空状態に保った のち、そのままの状態でシリコンオイルに浸す。このば あい膨潤効果が無視できることは、シリコンオイル処理 をしなくても長周期の求まる $90^{\circ} \mathrm{C}-60$ 分，95 9 - 30 秘， 1 分で熱処理したものと，これをシリコンオイル処理し 
てから求めた倠とを比較して確かめた ${ }^{18)}$ 。

\section{3. 実験結果}

\section{1 キシレン処理による長周期の変化}

処理温度と時間変化に伴う小角回折像を図 1 に示寸。 すへててっット面に平行な edge 方向からのものである。 写真には $T_{c}=77$ +試料をのせたが $T_{c}=80$ +試料も同様な

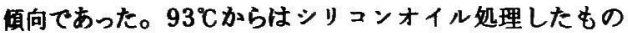
である。100ㄷー10分はシリコン処理していない。 小角回折写真から算定して，60 分熱処理での温度に よる長周期変化を図 2 に，また各温度における長周期の 時間的変化を図 3 に示した。参考のために, 同じ試料に
ついて, 空気中で熱処理したばあいにえられる長周期変 化を図 4 ，図 5 に揭げた。

これらの実験結果で注目すべき点をあげると次のとお クである。(1)キシレン処理では $92^{\circ} \mathrm{C} \sim 93^{\circ} \mathrm{C}$ 付近で突 如として長周期の增大が始まる。それ以下の温度ではほ とんど長周期の増大はみられない。(2)この長周期の増 大は不連続的であって, 空気中熱処理のばあいの厚化上 举動が異なっている。（3）時間的にも長周期は不連続的 に增大して以後ほとんど変化しない。これも空気中熱処 理によるもの（図 5 ) とはやや異なっている。(4) キシレ ン処理の初期では, 小角回折像の $92^{\circ} \mathrm{C}-10$ 分, $95^{\circ} \mathrm{C}-$ 1 分のものにみられるようにOriginal 層厚の部分と熱

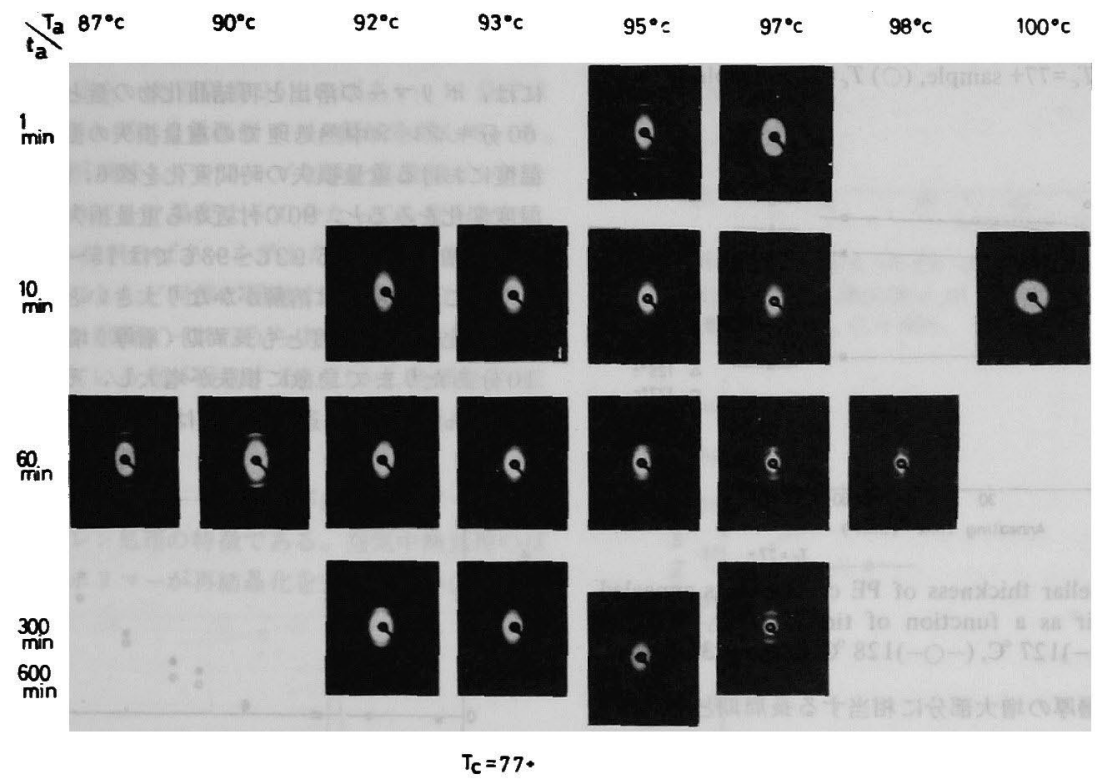

Fig. 1 Small-angle diffraction patterns of PE crystal mats, annealed in xylene for times $\left(t_{a}\right)$ 1 to $600 \mathrm{~min}$ at temperature ranges $\left(T_{a}\right) 87-100{ }^{\circ} \mathrm{C}$.

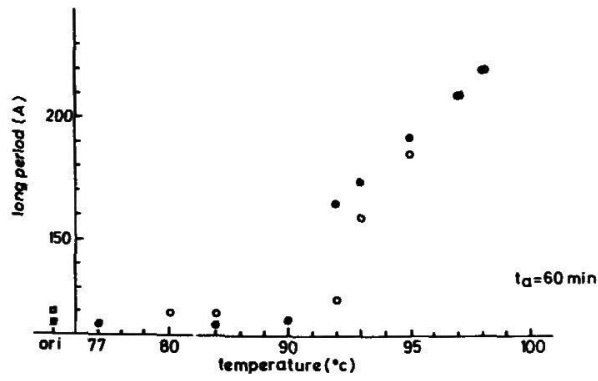

Fig. 2 Lamellar thickness of PE crystal mats annealed in xylene as a function of temperature. (O) $T_{c}=77+$ sample, (O) $T_{c}=80+$ sample.

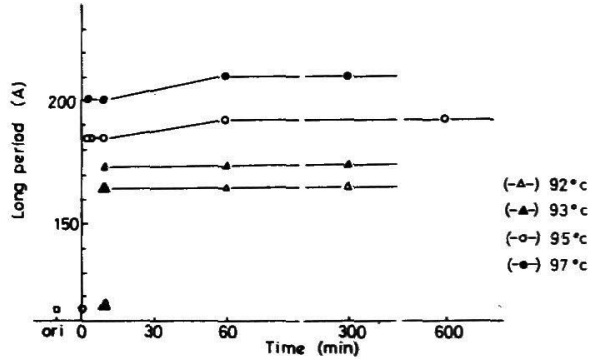

Fig. 3 Lamellar thickness of PE crystal mats annealed in xylene as a function of time. $(-\Delta-) 92{ }^{\circ} \mathrm{C}$, $(-\Delta-) 93^{\circ} \mathrm{C},(-\mathrm{O}-) 95^{\circ} \mathrm{C},(--) 97{ }^{\circ} \mathrm{C}$. 


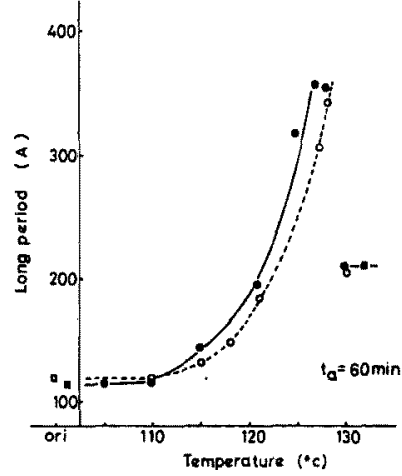

Fig. 4 Lamellar thickness of PE crystal mats annealed in air as a function of temperature.

(C) $T_{c}=77+$ sample, (O) $T_{c}=80+$ sample.

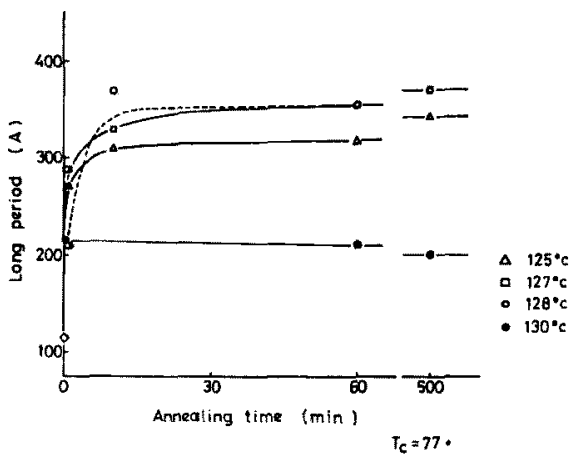

Fig. 5 Lamellar thickness of PE crystal mats annealed in air as a function of time. $(-\triangle-) 125^{\circ} \mathrm{C}$ $(-\square-) 127^{\circ} \mathrm{C},\left(-\mathrm{O}^{-}\right) 128^{\circ} \mathrm{C},\left(--_{-}\right) 130^{\circ} \mathrm{C}$.

処理による圈厚の增大部分に相当する長周期とが共存し ている。この共存状態のより大きな長周期は，この時間 でほぼ時間的変化を終っている。（5）長周期の增大の速

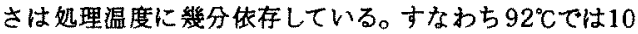
分でもまだ共存状態にあり，950では 1 分で共存状態で， 3 分では完了している。これは $92^{\circ} \mathrm{C} て ゙ は ~ 95^{\circ} \mathrm{C}$ 上も部 分溶解の速度が遅いことに起因するのであろう。

\section{2 配向の変化}

空気中処理では $127^{\circ} \mathrm{C}$ 以上の高温域になると去角 X 線 回折像にはマット面に対して結晶分子鎖が㑯いて， $a$ 軸 配向ないし row structureなどの特殊配向を示すような

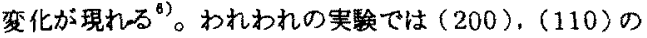
強度分布の比較から $a$ 軸配向が主であって, 結晶 $c$ 軸が マット面の垂線上なす頃角 $\chi_{t}$ の值は表 1 のように変化す ることが知られた。

しかるにキシレン中の熱処理㜞燥物においては，部分 溶解が限度に達する $100^{\circ} \mathrm{C}-10$ 分以下のいずれの温度に
Table 1 Change of the tilt angle $\chi_{c}$ with the heat treatment in air (temperature $T_{a}$, time $t_{b}$ ) of PE crystal mats (crystallized at $T_{c}$ ).

\begin{tabular}{|c|c|c|c|}
\hline$T_{c}\left({ }^{\circ} \mathrm{C}\right)$ & $T_{a}\left({ }^{\circ} \mathrm{C}\right)$ & $t_{a}(\mathrm{~min})$ & $\chi_{c}(\mathrm{deg})$ \\
\hline \multirow{2}{*}{$80+$} & \multirow{2}{*}{128} & 60 & 59.4 \\
& & 600 & 64.4 \\
\hline \multirow{2}{*}{$77+$} & \multirow{2}{*}{128} & 60 & 46.5 \\
& & 600 & 52.8 \\
\hline
\end{tabular}

抒いても厷角X線回折像にはOriginal バターンとほほ 同様で特殊配向が見られなかった。したがってキシレン 処理のばあいの配向はOriginal 陚料の配向をそのまま 保持するものと考えられる。

\section{3 キシレン中熱処理による重量損失}

キシレン中ではポリマーが容解し、マットの重量損失 には、ポリマーの溶出と再結晶化物の量とが反映する。 60 分キシレン中熱処理での重量損失の温度化拉よび各 温度における重量損失の時間変化を図6，図7に示した。 缊度変化をみると，90 $\mathrm{C}$ 付近から重量損失が始っている。 長周期增大の現れる $92^{\circ} \mathrm{C} \sim 93^{\circ} \mathrm{C}$ では 15〜20\%の提失が あり，この温度では溶解がかなり大きいと思われる。時 間的変化は，各温度とも長周期 (層厚) 增大が完了する 10分あたりまで急激に損失が增大し，その後はゆるゃ かになって 60 分を過ぎてからは 300 分，600分たって

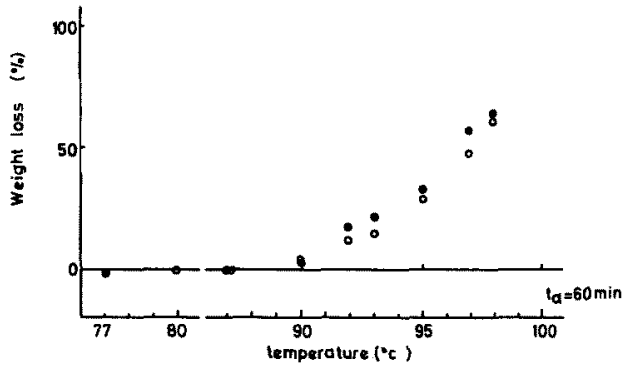

Fig. 6 Weight loss of PE crystal mats on annealing in xylene as a function of temperature.

(O) $T_{c}=77+$ sample, (O) $T_{c}=80+$ sample.

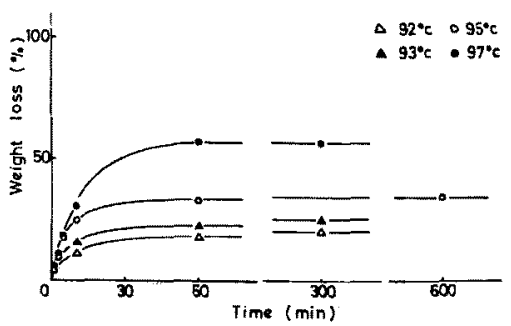

Fig. 7 Weight loss of PE crystal mats on annealing in xylene as a function of time. $(-\triangle-) 92^{\circ} \mathrm{C}$, $(-\Delta-) 93^{\circ} \mathrm{C},(-\mathrm{O}-) 95^{\circ} \mathrm{C},(-0) 97^{\circ} \mathrm{C}$. 
もほとんど变化しなくなる。これは再結晶化によると思 われる。

$77+$ 試料に比べて $80+$ +試料の提失は温度に対して数 かの扰くれが誌められる。

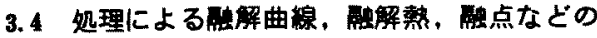
变化

\section{(1) DSC整罪曲缐}

キシレン中熱処理乾燥物でえられるサーモグラフを， 処理温度別，処理時間別に画いて図8に示した。重量損

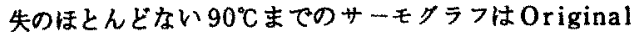
試料にみられる三つの歌解ピークの痕跡を牫している。重 量損失が 10 数かで溶解が進んでいると考えられる $92^{\circ} \mathrm{C}$ 付 近から単一ピークとなる。シャーブな単一ピークは $98^{\circ} \mathrm{C} ま$

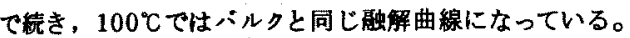
時間的にみると，処理温度 $95^{\circ} \mathrm{C}$ ゆ゙あい，1 分では Original 試料と同しく低温側ビーク領域を残している。 10 分でそれが消减してシャーブな単一高温側ピークと なり，以後このビーク缊度は 600 分たっても変らない。 困には 77+試料のばあいを示したが，80+試料のサ ーモグラムもほとんど同様に程過する。ただ.Original 武料では三つの䜿解ピーつのうち中央領域が高温領域よ ク大きくなっている点が相違する。しかし処理温度 92 ${ }^{\circ} \mathrm{C}$ 以上，時間 10 分以内に逆転して，その後は高温側単 一ビークが形成される。

いずれにしても、サーモグラが鋭い単一ビークとな ることはキシレン处理の特敳である。空気中熱処理のば あいは，融解ポリマーが再結昆化を完了しない分だけ瓷

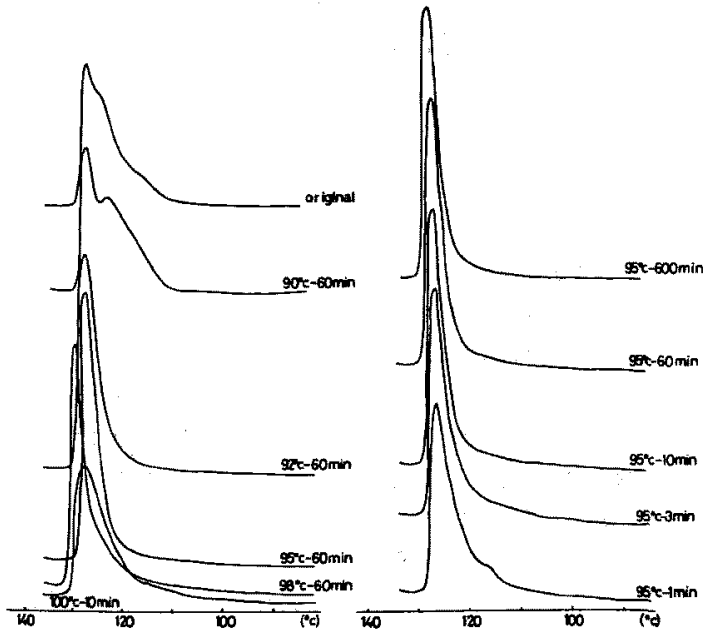

Fig. 8 DSC thermograms of PE crystal mats annealed in xylene for different temperature and for various times.
却時に固化することによってサーモグラムには二重ピー クを形成する ${ }^{18)}$ 。

\section{(2) 鰠解熱}

サーモグラムから求められた融解熱は，60 分奶理の ものについての温度变化が図 9 のように，また処理時間 に対する变化が図10のようになる。時間に関しては， 短時間で一度䙌解熱が減少し再び增大する。この傾向は

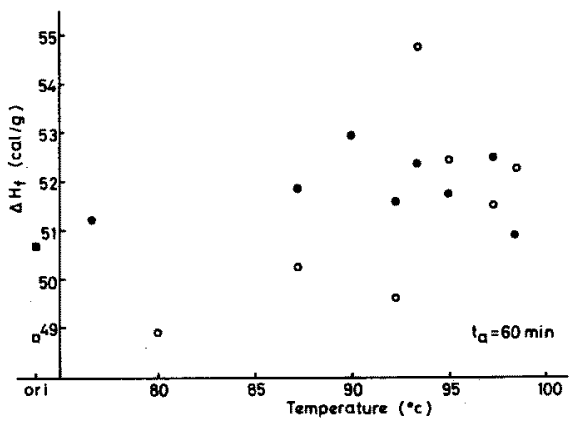

Fig. 9 Heat of fusion of PE crystal mats annealed in xylene as a function of annealing temperature. (O) $T_{c}=77+$, (O) $80+$.

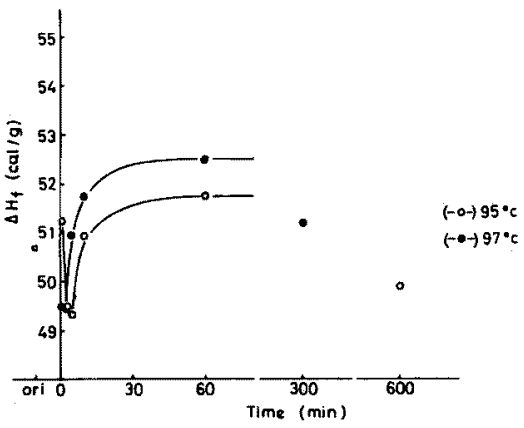

Fig. 10 Heat of fusion of PE crystal mats annealed in xylene as a function of annealing time.

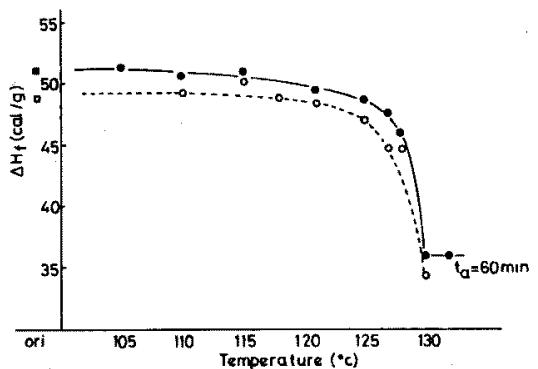

Fig. 11 Heat of fusion of PE crystal mats annealed in air as a function of annealing temperature. (O) $T_{c}=77+$, (O) $T_{c}=80+$. 
空気中の熱処理（図 12）でもみられる。キシレン処理に おける融解熱の温度依存性は，温度とともに多少增加し ている程度である。空気中熱処理のばあい（因 11)のよ うに, 配向変化を伴う高温域で融解熱が减少するという 明白な現象はキシレン処理試料では認められない。

(3) 腒 点

キシレン処理による融点の変化は， 60 分処理での各 温度に対するもの，各温度での時間によるものを示すと，

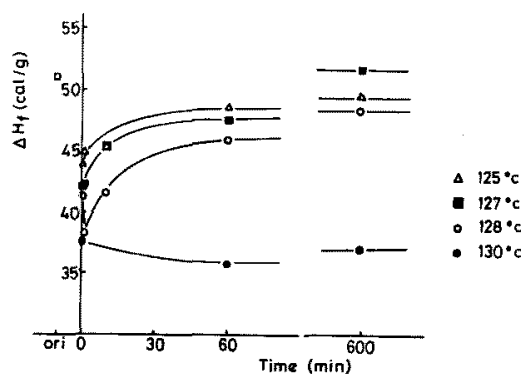

Fig. 12 Heat of fusion of PE crystal mats annealed in air as a function of annealing time.

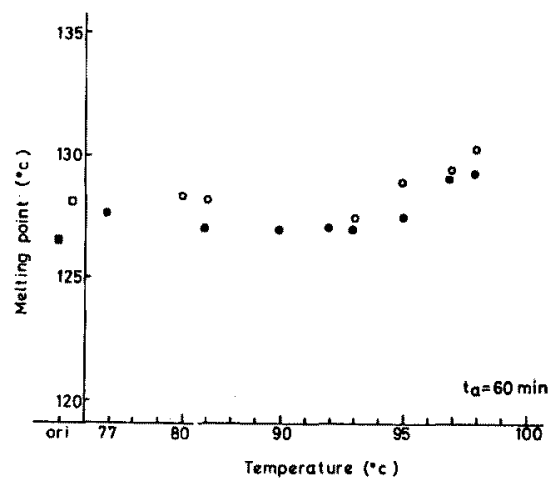

Fig. 13 Plot of melting temperatures of PE crystal mats annealed in xylene as a function of temperature. (O) $T_{c}=77+$, (O) $T_{c}=80+$.

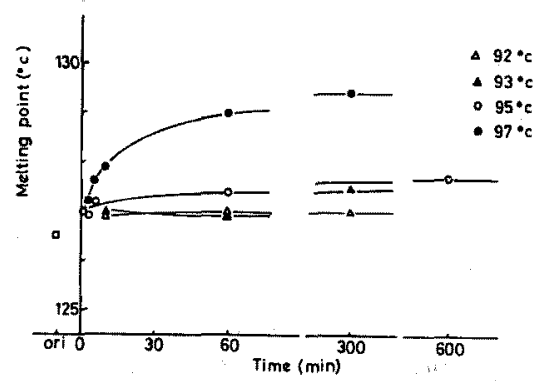

Fig. 14 Plot of melting temperatures of PE crystal mats annealed in xylene as a function of time.

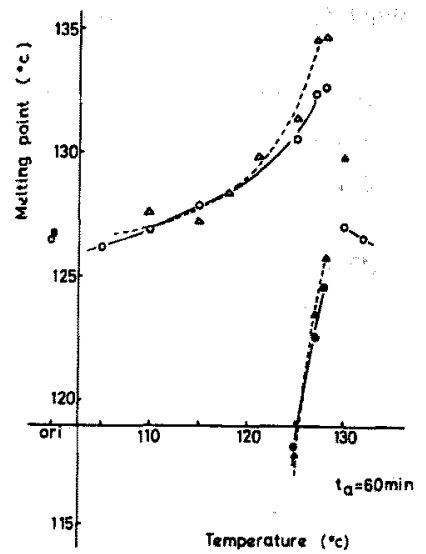

Fig. 15 Plot of melting temperatures of PE crystal mats annealed in air as a function of temperature. (O) $T_{c}=77+,(\Delta \Delta) T_{c}=80+$.

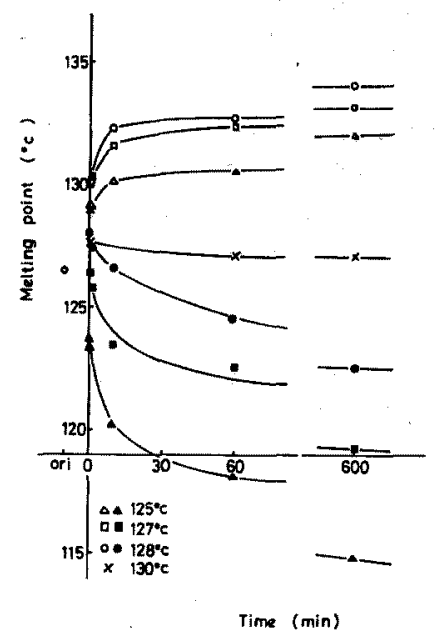

Fig. 16 Plot of melting temperatures of PE crystal mats annealed in air as a function of time.

それぞれ困 13，困14のとおりである。温度変化では93ㄷ までほとんど変わりがなく，95 Cから上がり始める。時 間的には高温になるほどその上昇が影著になっている。 空気中熱処理のばあい（図 15，図16)に高温域で特徵的 となる，時間的に上昇する高蜃点上時間的に低下寸る低 融点との両者の存在という現象"は見られなかった。

\section{5 表面エネルギー $\left(T_{m}-l^{-1}\right.$ 関㜀 $)$}

キシレン処理したPE 単結晶マットの茫蝶物について， サーモグラムの䖯点 $T_{m}$ とその長周期 $l$ 逆数から図 17 に示すような $T_{m}-l^{-1}$ 関保がえられる。揤定可能範围が 狭いため多少無理ではあが，直線関係があると思われ るのでHoffman -Weeks 式を通用してみる。すなわち 

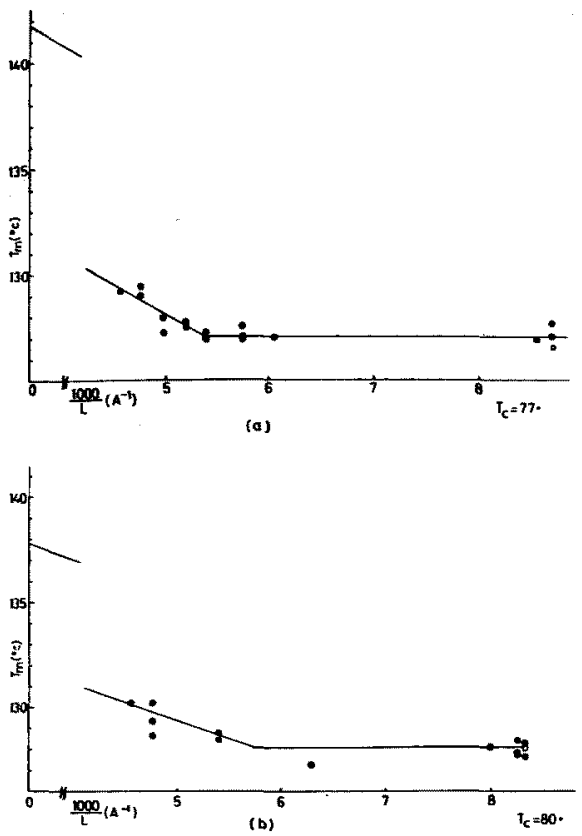

Fig. 17 Plot of the melting temperature $\left(T_{m}\right)$ against reciprocal of the long period $(l)$ for PE crystal mats annealed in xylene.

(a) $T_{c}=77+$, (b) $T_{c}=80+$.

Table 2 Estimates of $T_{m}^{0}, \sigma_{e}$ for PE crystal mats annealed in xylene.

\begin{tabular}{|c|c|c|c|}
\hline$T_{c}\left({ }^{\circ} \mathrm{C}\right)$ & $T_{a}\left({ }^{\circ} \mathrm{C}\right)$ & $\left.T_{m}{ }^{\circ}{ }^{\circ} \mathrm{C}\right)$ & $\sigma_{e}\left(\mathrm{e} \mathrm{rg} / \mathrm{cm}^{2}\right)$ \\
\hline $77+$ & \multirow{2}{*}{$77 \sim 98$} & 141.8 & 92 \\
\hline & & 137.8 & 57 \\
\hline
\end{tabular}

$T_{m}=T_{m}^{0}\left(1-2 \sigma_{e} / \Delta h_{f} l\right)$ で近似する。 $T_{m}$ 観湘点 $T_{m}^{0}$ 平衡 融点， $\Delta h_{f}$ 融解熱， $\sigma_{e}$ 表面エネルギー, $l$ ラネラ曆であ る。

$l=\infty$ K外捜してえられる $T_{m}^{0}$ の值と， $\Delta h_{f}=28 \times 10^{\circ}$ erg $/ \mathrm{cm}^{3}$ とおいて ${ }^{*, B)}$ 求めた $\sigma_{e}$ の値を表 2 に示した。こ の程度の值は, Huseby, Bairら ${ }^{8)}$ がキシレン容媒の存 在下で求めた $T_{a}^{0}=113.7 \pm 1.2^{\circ} \mathrm{C}, \sigma_{e}=93 \pm 8 \mathrm{erg} / \mathrm{cm}^{2}$ お よび容媒のないばあいの $T_{m}^{0}=145.8 \pm 1^{\circ} \mathrm{C}, \sigma_{e}=89 \pm 5$ $\mathrm{erg} / \mathrm{cm}^{2}$ の値と较べて，ほぼ妥当なものである。

ここで比軹のために，楁媒のない空気中熱処理によっ てえられる $T_{m}-l^{-1}$ 関原を図 18 に示した。すれわれの 試料のばあい，処理温度 $123^{\circ} \mathrm{C}$ 付近を境にして高温傊， 低温溉で異なった㑯きをもった直線を生じている。それ ぞれの直線がHoffman - Weeks 式に従うと仮定し， $T_{m}^{0}$, 。の值を求めると表 3 のようになる。低温域の $T_{m}^{0}$ の值 は通常の平嫐点にくらべて低くなっているが，高温域の

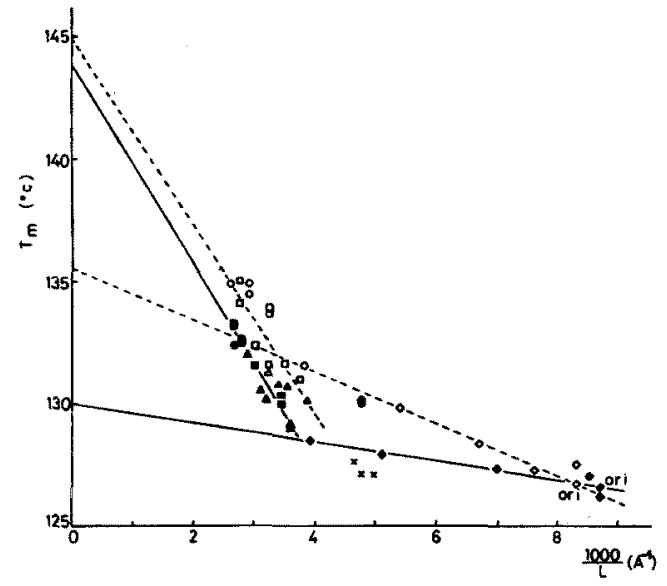

Fig. 18 Plot of the melting temperature $\left(T_{m}\right)$ against reciprocal of the long period $(l)$ for PE crystal mats annealed in air.

(closed) $T_{c}=77+$, (open) $T_{c}=80+$.

Table 3 Estimates of $T_{m}^{0}, \sigma_{e}$ for PE crystal mats annealed in air.

\begin{tabular}{|c|r|c|c|}
\hline$T_{c}\left({ }^{\circ} \mathrm{C}\right)$ & \multicolumn{1}{|c|}{$T_{a}\left({ }^{\circ} \mathrm{C}\right)$} & $T_{m}{ }^{\circ}\left({ }^{\circ} \mathrm{C}\right)$ & $\sigma_{e}\left(\mathrm{erg} / \mathrm{cm}^{3}\right)$ \\
\hline \multirow{2}{*}{$77+$} & $\sim 123$ & 130.1 & 14.2 \\
\cline { 2 - 4 } & $125 \sim 128$ & 143.9 & 135.9 \\
\hline \multirow{2}{*}{$80+$} & $\sim 121$ & 135.6 & 36.3 \\
\cline { 2 - 4 } & $125 \sim 128$ & 144.9 & 127.8 \\
\hline
\end{tabular}

それはほぼ近い。また $\sigma_{e}$ の値は通常の30〜 $180 \mathrm{e} \mathrm{rg} / \mathrm{cm}^{2}$ にくらべで，低温域ではかなり低く，高温域では高い 方である。

キシレン処理試料の表面エネルギーが空気中熱処理の 低温側, 高温側処理域でえられる值の中間値をもつこと が注意される。

\section{4. 実験結果の考察}

\section{1 キシレン好理における層匽の変化}

キシレン中の熱処理については，平井ら はキシレン 和㴼中で熱処理しても空気中熱処理と同じような厚 化反庆が起こると報告している。そしてキシレン中では

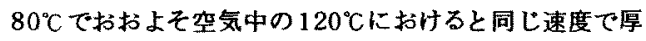
化が進むとしている。

またHolland ${ }^{4}$ は希薄容夜から単結晶を析出し、この サスベンションをゆっくり heating して, そのモロホロ ジー变化を電子影䍌で調べて, heating で結晶端の部 分溶解が生じ溶晸ボリマーは再結晶して更に heating ると緑だけ結晶のま残り，内僋が客解している“picture - frame”結晶を観察している。そしてキシレン 処理で、末溶解結晶を便宜上の核として再結晶が生じ 
るのであって，平井らがいうような空気中熱処理に㧍け ると同じく creep upによってある厚さから他の厚さに 結晶層が增大するとする見解には同意していない。

われわれの実駼は，単結晶マットによる測定であるが， キシレン中の熱処理はHollandと同じようにpureの容 媒あるいは希薄溶液中で行われている。舆閭期(層厚)

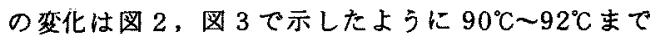

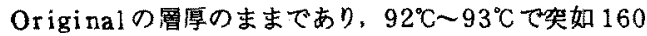
A〜 175 ̊の値に增大し，この温度では図6，区7に見 られるように重量損失が 15〜20\%とかなり多くなる。 これは罒9，図10の融解熱の変化を併せ考えることに よりキンレン処理中にマット内では部分溶解が生じ溶解 ポリマーが再結晶しているとみてむよいであろう。試み にキシレン希薄溶液から等温結晶化で成長するポリエチ レン単結晶の厚さを，従来の報告から調べてみると，表 4のと抢りである。これらの值は本奏験でえられる図 2 の値にほぼ匹敵している。

Table 4 Lamellar thickness ( $l$ ) of PE crystals grown from dilute solutein in xylene.

\begin{tabular}{|c|l|c|}
\hline$T_{c}\left({ }^{\circ} \mathrm{C}\right)$ & $l(\AA)$ & Ref \\
\hline 90 & 145 & $8)$ \\
& 141 & $9)$ \\
& 142 & $10)$ \\
& $154 \pm 1$ & $11)$ \\
92.5 & $172 \pm 1$ & $11)$ \\
95 & 178 & $8), 12)$ \\
100 & 275 & $10)$ \\
\hline
\end{tabular}

な㧍注目すべきことは，Original 層厚部分とキシレ ン処理で増大した層厚部分が，小角 X 線回折像に鮮明に 現われるほどの共存状態があって，この状熊あるいは熄 大完了まては重量損失が比較的多くて，完了後は長周期 (㬝厚)の変化がなくなると共に重量変化もほとんどみ られなくなることである。そしてその祭，分子鎖の配向 はほぼもとのまま文保持している。以上の事実は，キシ レン液中の熱姏理においてはOriginal 結晶の弱い部分 からまたは結晶の端部分から溶解を始め，重量損失にあ ずからない溶解部分が，牫存している結晶の配向と煫つ て，その温度で規定される痛厚で再結晶する，という機 满で説明される。これはHollandが電子顕燿鏡覾察から えた結論にほぼ一致するものである。

\section{2 空気中熱処理における厚化過程との現象的 な差異}

空気中の熱処理ではキシレン液中におけるような溶 解による重量損失はおこらない。このばあい溶解に相当 する現象はポりマーの䝠解である。触解ボリマーは熱好 理中その温度と時間できまる分量だけ再結晶化する。再
結晶しないで夙解状態で残っている分は，陚科を急合す る時に，一度に結晶するであろう。

われわれの陚料についていえば, 処理温度 $T_{d}=118$

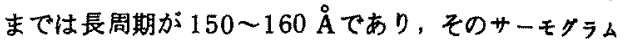
にはOriginal 試料にみられる三つの蛅点ピークの痕踈 が残っていて，ほぼ初めの形熊が保持されている。訟角 $\mathrm{X}$ 線回折像でも分子鎖の配向は変っていない。この得度 域では䖪解が少く，大部分がすぐ結晶化してしまうもの と思われる。 $T_{a}=121^{\circ} \mathrm{C}$ 付近ではサーモグラムは嵪愠寄 りに単一融点ピークをもったものとなる。 $T_{a}=123^{\circ} \mathrm{C}$ 付 近からは，その融点を图 15 に示したように，低淈賻 一ク領域が出てきて， $T_{a}=128^{\circ} \mathrm{C}$ まで离温側ピーク領城 と二つの領域をもったサーモグラムとなる。このとき長 周期注 4 で見たように急湤に增大し，分子銧も 3.2 项 で述べたような特殊配向をする。

熱処理温度 $T_{a}=123^{\circ} \mathrm{C} \sim 128^{\circ} \mathrm{C}$ の段階では, 再結晶部 分と䖪解部分とが共存状態にある。能解部分は試料の急 冷によって結晶物となるであろう。サーモグラムの低温 僋ピーク領域の形成が，この急冷結晶物に因るという見 解は前田ら"の述べているところであり，われわれも同 様な手法でこれを確かめた。

$T_{a}=130^{\circ} \mathrm{C}$ ではサーモグラムは単一ビークを示すが， これは $T_{a}=128^{\circ} \mathrm{C}$ まで低温側ピーク領域が 100 かな ったものと考えることができる。そこでサーモグラムの この領城の全体に対する比率をとって，処理温度 $T_{a}$ ，処 理時間 $t_{a} に$ 詨して画けば，熱好理中その時点で牫存する 融解ポリマー壆の目やすとなる。因19kこれを示す。 ただし低温側ピーク領域の分離は，その裙で奶線をひい てぺースラインまで外挿しておこなった。この図で徉軸 が 100 とと曲線との間隔は，処理時間に対して，憵解し たものが再結晶化する分率を表わしている。 っても時間 $t_{a}$ が释過すれば再結晶化の量は增えてゆく。 このばあい先に図 16 で示したように低温側ピーク敄域 の触点が時間的に減少していることは，分別結晶化が行 われていることを思わせる。また仮に空気中の虽解术り

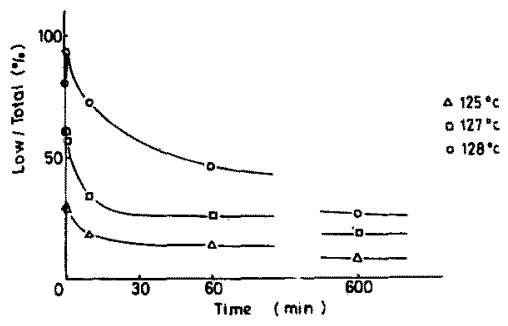

Fig. 19 Plot of the ratio of $\Delta H_{f}$ with lower melting temperature and total $\Delta H_{f}$ of PE crystal mats annealed in air as a function of annealing time. 
マーがキシレン中では容出するとすれば図 19 の曲線を 摃分したものは，キシレン中熱処理のばあいの重量梖失 (因7)に関連つけられるであろう。キシレン中でも分子 量の小さいものが先に容出してしまって, 再結晶化は分 别的におこなわれると考えられる。な㧍先に 3.2 項で述 べた空気中熱処理の厚化に伴う特殊至向は，この再結晶 化の過程て形成される。この際, 呑向を保持した末融解 部分の存在を必要とするようである。末融解部分を何ら

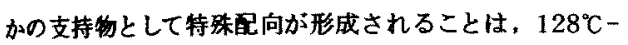
60 分熱処理したものを命却後再び $125^{\circ} \mathrm{C}-60$ 分処理す ると，厷角回折像が直接 $125^{\circ} \mathrm{C}$ て熱処理したものにほぼ 居ること，また低㬈から逐次 60 分づつの熱処理と急冷 を嬠返して最後に $T_{a}=128^{\circ} \mathrm{C}$ とたものは眍向がOriginal 試料と同程度であるし， $T_{a}=130^{\circ} \mathrm{C} の も の$ 性直接 128 Cで熱処理したものと同栚な棌向となる、などから 屯推定される。

キシレン中の菑解分子鎖にくらべて、空気中の能解分 子鋇恃束練状態にあって運動の自由度が少いため，この ような形態的な差を生じるのであろう。

\section{5. 結 論}

未分別ボリエチレンを用い，キシレン希薄榕䧹から単

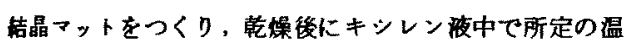
度、時間で熱処理を抽なった。処理の䊏了時点で急命 し䫧煤した試料について，キシレン処理によって生じる 層厚の增大を考察した。実跧結果の主なものは次のとお クでった。

1）重量損失は処理温度 $90^{\circ} \mathrm{C}$ 付近から始まり，それま ては長周期は变化しない。長周期の增大があらわれる92 て 93ㄷ C゙は重量損失が 10〜20タとなる。そのばあい 時間的には重量椇失も 10 分以内で大勢が決まり，60分 以漛梳 600 分経ってもほとんど変らない。

2） $90^{\circ} \mathrm{C}-10$ 分また $95^{\circ} \mathrm{C}-1$ 分処理試料の小角回折 像に、末処理時の層厚と処理によって堌大した層厚に相 当するニつの長周期が併存して見われる。

3）空気中熱処理試料の広角回折像でみられる分子鎖 の特殊至向は，キシレン処理のばあいは現われず目向は 变化しない。

4）融解サーモクラムは，急冷後のものであるにもか かわらず, $92^{\circ} \mathrm{C}$ 以上処理試料でシャーブな単一ピーク領 城のみである。ピーク嗢度と長周期の $T_{m}-l^{-1}$ 関保から えられる表面エネルギー的の值は， $92 \sim 57 \mathrm{erg} / \mathrm{cm}^{2} の$ 程度である。

以上の結果は, 異った処理温度・時間の試料に対して

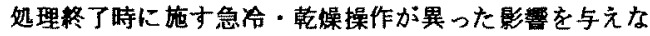
いとすればキシレン菠中のWet な状態での熱処理に伴 う層厚の增大を反映した理象と考えてよい。この祭，層 厚はほぼ一段階で增大し，その处理温度で規定される厚 さになっていることからみて，キシレン処理による層厚 の增大は溶媒の存在下てのポリマーの溶解 再結晶化の 過程によるであろうことが推諭された。なおキシレン中 の容解一再結晶化は，空気中熱処理における融解一再結 晶化の機满とも類似しているように思われる。空気中の ばあいは。キシレン容媒が存在しないことによって，再 結晶に扔ける特殊见向”など，現象的に恃違った形態が あらわれるのであろう。

な技末解部分に creep-upがおこるかどうかなど

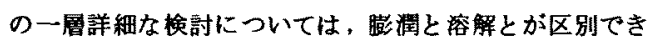
るような媒質中での利定、またPEを結晶化させる程度 が異ったキシレン以外の容媒などを用いた実験を行った 上で改めて行う必要があると考える。

\section{文献}

1) 平井西夫, 光姻照久, 山下秥 ; 高化, 18, 33 (1961)

2) A. Peterlin; J. Polymer Sci., Part-B 1, 279 (1963)

3) T. Kawai; Kolloid-Z., u. Z. Polymere, 201, 104 (1965)

4) V. F. Holland; J. Appl, Phys, 35, 59 (1964)

5) M. Maeda, K. Miyasaka and K. Ishikawa; J. Polymer Sci. Part A-2, 8, 1865 (1970)

6) F.J. Baltá Collejá, O.C. Bassett .and A. Keller; Polymer, 4, 296 (1963)

7) 河合 徽；高分子, 15,898(1966)

8) T.W. Huseby and H.E. Bair; J. Appl Phys., 34, 4969 (1968)

9) K. Ishikawa, K. Miyasaka and M. Maeda; J. Polymer Sci. Part A-2, 7, 2029 (1969)

10) A. Peterlin; Makromol Chem., 74, 107 (1964)

11) L. Mandelkern, R.K. Sharme and J.F. Jackson; Macromolecules, 3, 454 (1970)

12) P.J. Roe and H.E. Bair; Macromolecules, 3, 454 (1970)

13) Y. Udagawa and A. Keller; J. Polymer Sci, A-2, 9, 437 (1971)

14) E. Evgüz and L. Mandelkern; Polymer letter, 10, 631

15) A. Nakajima, S. Hayashi and N. Nishimura; KolloidZ. u. Z. Polymere, 229, 107 (1967)

16) E.W. Fisher and G. Hinrichsen; ibid, 247, 858 (1971)

17) I.C. Sanchez, J.P. Colson and R.K. Eby; J. Appl Phys., 44, 4332 (1973)

18) M. Takayanagi, F. Nagatoshi: 九州大学工学部䄫要, 24, 33 (1965), 高柳; 高分子科学の展望, 1970, p. 207. 